\title{
Silica zeolite scavenging of exhaled isoflurane: a preliminary report
}

\section{[Le captage de l'isoflurane expiré par la zéolithe de silice: un compte-rendu provisoire]}

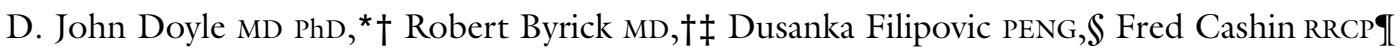

Purpose: We evaluate the effectiveness of a silica zeolite (Deltazite $^{\mathrm{TM}}$ ) hydrophobic molecular sieve adsorbent, in removing exhaled isoflurane.

Methods: In three experiments, a simulated anesthesia mannequin was ventilated using $1 \%$ isoflurane in nitrous oxide and oxygen ( $1: 1$ ratio) at a gas flow of $3 \mathrm{~L} \cdot \mathrm{min}^{-1}$. Airway pressures, end-tidal carbon dioxide $\left[\mathrm{ETCO}_{2}\right]$, inspired and end-tidal isoflurane were measured. The scavenging line was connected to a canister containing $750 \mathrm{~g}$ of the silica zeolite. Concentrations of isoflurane entering and exiting the canister were measured, as well as the pressure gradient across the canister and gas flow through the canister. In phase I $(n=3)$, the mannequin was ventilated for $6.5 \mathrm{hr}$, followed by phase 2 where a test lung replaced the simulator. The time (phase I plus phase 2) until isoflurane 'breakthrough' (> $0.02 \%$ ) was noted.

Results: The average canister weight increase was $68 \mathrm{~g}$, however $92 \mathrm{~g}$ of isoflurane were used. The isoflurane concentration exiting the canister remained undetectable throughout phase $\mid$ in each experiment. The pressure gradient across the canister averaged $0.13 \mathrm{~cm} \mathrm{H}_{2} \mathrm{O}$ and did not increase throughout phase I. The time to 'breakthrough' (phase I plus phase 2) was $8.0 \mathrm{hr}, 8.8 \mathrm{hr}$ and $9.0 \mathrm{hr}$.

Conclusions: Silica zeolite was effective at completely removing $1 \%$ isoflurane from exhaled gases for periods of eight hours. The technology shows promise in removing isoflurane emitted from anesthesia machine scavenging systems.

Objectif : Évaluer l'efficacité d'un adsorbant de zéolithe de silice (Deltazite ${ }^{\mathrm{T}}$ ), tamis moléculaire hydrophobe, pour éliminer l'isoflurane expiré.

Méthode : Trois essais ont été réalisés. Une anesthésie a été simulée sur un mannequin ventilé avec de l'isoflurane à I \% dans du protoxyde d'azote et de l'oxygène (ratio de l: I) selon un débit de gaz de $3 \mathrm{~L} \cdot \mathrm{min}^{-1}$. Les pressions des voies aériennes, le gaz carbonique télé- expiratoire $\left[\mathrm{ETCO}_{2}\right]$, l'isoflurane inspiré et télé-expiratoire ont été mesurés. Le tube d'évacuation a été relié à une boîte contenant 750 $g$ de zéolithe de silice. Les concentrations d'isoflurane entrant et sortant de la boîte ont été mesurées, de même que le gradient de pression traversant la boîte et le débit du gaz dans la boîte. Dans la phase I ( $n=3)$, le mannequin a été ventilé pendant $6,5 \mathrm{~h}$, puis à la phase 2, un poumon d'essai a remplacé le simulateur. Le temps (phase I plus phase 2) écoulé jusqu'à ce que l'isoflurane "apparaisse" (>0,02 \%) a été noté.

Résultats : Le poids moyen de la boîte a augmenté de 68 g, même si $92 \mathrm{~g}$ d'isoflurane ont été utilisés. La concentration d'isoflurane sortant de la boîte est demeurée indétectable pendant toute la phase I de chaque essai. Le gradient de pression au travers de la boite était en moyenne de $0,13 \mathrm{~cm} \mathrm{H}_{2} \mathrm{O}$ et n'a pas augmenté pendant la phase 1. Le temps écoulé jusqu'à "l'apparition" de l'isoflurane (phase I plus phase 2) a été de 8,0 h, 8,8 h et 9,0 h.

Conclusion : La zéolithe de silice a été efficace pour éliminer complètement l'isoflurane à I \% des gaz expirés pendant huit heures. La technologie semble prometteuse pour éliminer l'isoflurane émis par les systèmes d'évacuation des appareils d'anesthésie.

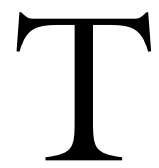

HE standard operating room 'gas scavenging system' collects and removes waste anesthetic gases and vapours and ensures that they are evacuated outside the working environment, usually to atmosphere. ${ }^{1,2}$

Some halogenated anesthetic agents are potent "greenhouse gases". It has been estimated that anesthetic emissions constitute approximately $0.01 \%$ of total chlorofluorocarbon (CFC) emissions. ${ }^{3}$ Total "greenhouse gases" are largely the result of industrial pollution and the burning of fossil fuels, not anesthet-

From the University Health Network;* Department of Anaesthesia,† University of Toronto; Department of Anaesthesia, $\ddagger$ St. Michael’s Hospital; Blue-Zone Technologies Ltd; $\$$ and the Patient Simulation Centre, $\mathbb{I}$ St. Michael's Hospital, Toronto, Ontario, Canada. Address correspondence to: Dr Robert J. Byrick, Department of Anesthesia, University of Toronto, Room 132, Fitzgerald Building, 150 College Street, Toronto, Ontario M5S 1A8, Canada. Phone: 416-978-4306; Fax: 416-978-2408; E-mail: robert.byrick@utoronto.ca Conflict of interest statement: Although the authors are not paid consultants to Blue-Zone Technologies, Ltd, the company has agreed to donate a percentage of profits to a Department of Anesthesia Research Fund at the University of Toronto, where the authors hold academic appointments.

Accepted for publication February 26, 2002.

Revision accepted June 10, 2002. 
ic emissions. ${ }^{3,4}$ Many industries have reduced CFC emissions, including some medical industries that reduced CFCs in aerosols. No major change in the structure or function of anesthetic waste gas scavenging systems has been introduced; thus we anticipate that the proportion of atmospheric CFC contributed by waste anesthetics will increase.

A Canadian company developed a technology to remove, recover and reclaim halogenated hydrocarbons in a gas stream (U.S. patents $5,515,845$ and $5,231,980)$. This technology, protected by worldwide patents, is based on unique properties of a silica zeolite, which functions as a molecular sieve adsorbent. ${ }^{5,6}$ The basic technical process for the recovery of halogenated hydrocarbons from an anesthetic gas stream involves passing the exhaled gas through a bed of the hydrophobic and organophilic molecular sieve adsorbent, such as silica zeolite. Such an adsorbent has pore diameters large enough to permit molecules of the halogenated hydrocarbons to be selectively adsorbed in the large internal cavities of the crystal framework (Figure 1), thus removing halogenated hydrocarbons from the gas stream. This process continues until the adsorbent material is saturated and "breakthrough" of the hydrocarbons occurs, at which point the adsorbent material with the adsorbed halogenated hydrocarbons should be removed from the system and replaced with a fresh canister of new adsorbent. The technology has been commercialized for recovery of CFC compounds from industrial emissions. ${ }^{6}$

The exhausted adsorbent can be subsequently regenerated by exposure to a purging gas stream. The halogenated hydrocarbons are then reclaimed from the purging gas stream as liquid and purified for reuse by distillation and further processing. One report showed that adsorbed desflurane could be recovered as a liquid anesthetic agent by "desorption" process. This is a preliminary technical evaluation of the effectiveness of a silica zeolite (Deltazite ${ }^{\mathrm{TM}}$ ) in removing isoflurane emissions in a simulated clinical environment (Figure 2). This technical evaluation was undertaken using a simulated anesthesia mannequin before clinical trials. The silica zeolite is contained in a canister that is interposed in the evacuation system of a standard waste scavenging system.

\section{Experimental methods and measurements \\ Phase 1}

A MEDSIM ${ }^{\mathrm{TM}}$ Eagle Simulated Anesthesia Mannequin (Eagle Simulation, Inc., Binghamton, New York, USA; Figure 2) was intubated with a size 8 endotracheal tube and ventilated with a tidal volume of $700 \mathrm{~mL}$ at a rate of 10 breaths $\cdot \mathrm{min}^{-1}$. This mannequin is designed to exhale carbon dioxide $\left(\mathrm{CO}_{2}\right)$ in clinically relevant concentrations. An anesthetic gas machine (Ohmeda Modulus, Rexdale, Ontario, Canada) was used and delivered $1 \%$ isoflurane in nitrous oxide and oxygen (ratio of $1: 1$ ) at a total fresh gas flow rate of $3 \mathrm{~L} \cdot \mathrm{min}^{-1}$. Airway pressures were monitored using a standard Bourdon pressure gauge. The end-expired concentration of carbon dioxide $\left(\right.$ Pet $\left.\mathrm{CO}_{2}\right)$ was monitored using the gas monitor (Ohmeda 5250 RGM, DatexOhmeda, Louisville, Colorado, USA), which also measured the concentration of inspired and end-tidal isoflurane administered to the mannequin. To simulate humidification of expired gas, the expiratory limb of the circle anesthetic breathing system was connected to a standard humidification device (Conchatherm III Servo Controlled Heater, Hudson Respiratory Care, Inc., Temecula, California, USA).

Using this simulated anesthetic environment, humidified expiratory gases containing carbon dioxide, nitrous oxide, oxygen and isoflurane, were vented into the prototype canister (Figure 3 ). The canister measured $11.2 \mathrm{~cm}$ in diameter and $24.2 \mathrm{~cm}$ in height (Figure 3). The canister contained approximately 750 $\mathrm{g}$ of silica zeolite, separated from the inlet and outlet ports by a wire mesh. The concentration of isoflurane, in addition to the concentration of nitrous oxide and oxygen from the vented scavenged gas, was analyzed using a Datex Puritan Bennett Capnomac ULTIMA monitor (Datex-Ohmeda, Louisville, Colorado, USA) (Figures 2 and 4 ). The concentrations of these gases and vapour were measured both entering and exiting the canister. The pressure gradient across the canister was measured using a magnehelic differential pressure gage (Dwyer Instruments Inc, Michigan City, Indiana, USA) calibrated from $0.0-2.0$ inches of $\mathrm{H}_{2} \mathrm{O}$. The flow rate of scavenged gas through the canister was measured using a Novametrix ventchek hand-held respiratory mechanics pneumotachometer with a neonatal flow transducer (Novametrix Medical Systems, Inc., Wallingford, Connecticut, USA). The scavenged gas was then evacuated through a "passive" scavenging system at atmospheric pressure. Three separate experiments were conducted using fresh silica zeolite. Phase 1 of each experiment was conducted for $6.5 \mathrm{hr}$ of continuous administration of $1 \%$ isoflurane. Expired carbon dioxide was maintained between 35 and $40 \mathrm{mmHg}$.

\section{Phase 2}

At the end of $6.5 \mathrm{hr}$ of continuous anesthetic administration, the simulated anesthesia mannequin was removed and replaced by a model lung (a 2 - $\mathrm{L}$ anesthesia bag). The anesthesia mannequin was not used 


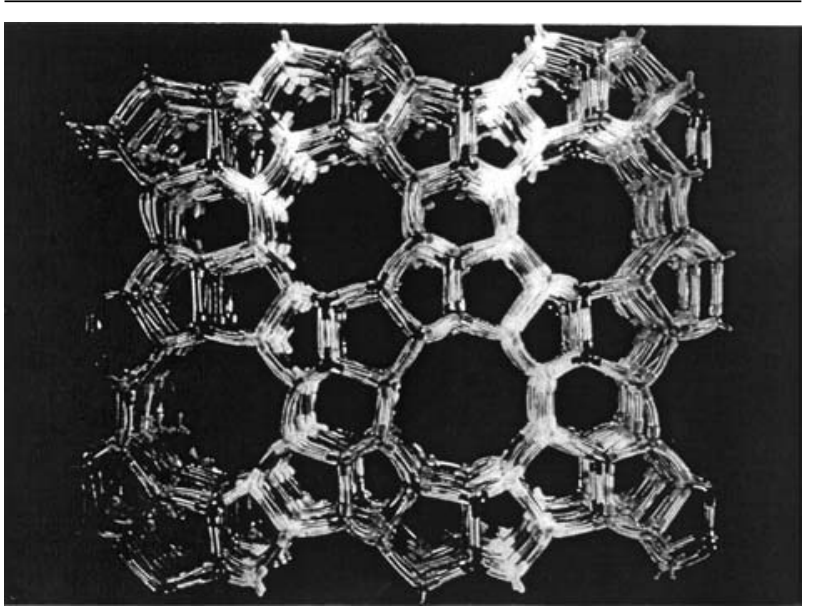

FIGURE 1 A repeated unit cell of the crystal structure of hydrophobic silica zeolite (Deltazite ${ }^{\mathrm{TM}}$ ) molecular sieve; target anesthetic agent is selectively captured in the honeycomb-shaped silica zeolite crystals. In just $500 \mathrm{~g}$ of silica zeolite, the total internal surface area available for capturing anesthetic would cover 70 football fields.

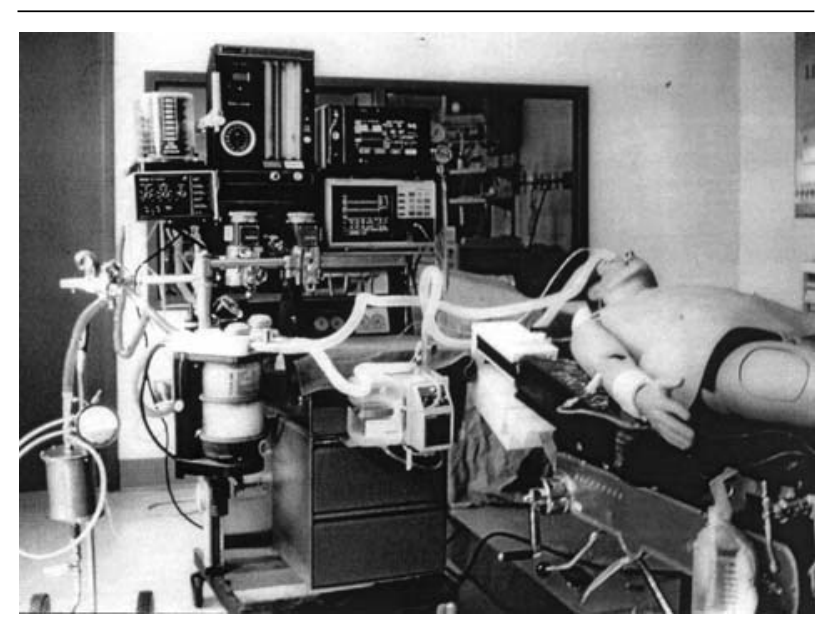

FIGURE 2 Deltasorb ${ }^{\text {TM }}$ canister testing at St. Michael's Hospital Patient Simulation Centre in Toronto.

continuously for prolonged periods of time, because of concerns related to preventive maintenance (overheating, etc). Phase 2 of the study did not use humidified gas containing $\mathrm{CO}_{2}$, just oxygen, nitrous oxide and isoflurane exiting the anesthesia machine. In phase 2 , only the concentrations of isoflurane, nitrous oxide and oxygen, from the gas exiting the canister were continuously monitored. We used the videotap-

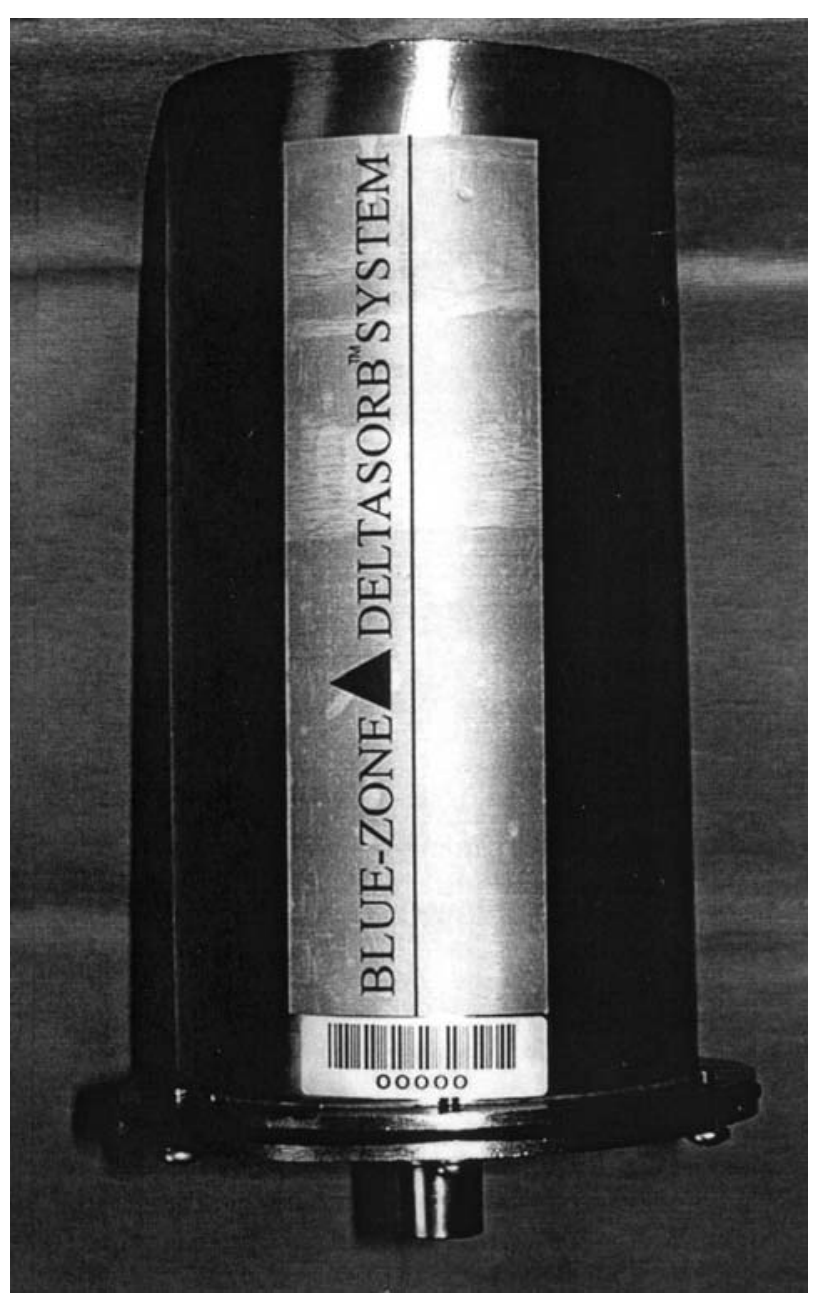

FIGURE 3 Deltasorb $^{\mathrm{TM}}$ canister used in the study.

ing facility in the simulation centre to record the time until isoflurane 'breakthrough', defined as the point at which the concentration of isoflurane exiting the canister was greater than $0.02 \%$.

In one experiment, the silica zeolite was allowed to become fully saturated. Full saturation was defined as occurring when the concentration of isoflurane exiting the canister was equal to the concentration entering the canister $(1.0 \%)$. We used a calibrated, continuous air flow metre (Checkmate, Bourns Medical Systems Inc., Riverside, California, USA) to study flow rate effects on canister resistance at $30 \mathrm{~L} \cdot \mathrm{min}^{-1}$ and 90 $\mathrm{L} \cdot \mathrm{min}^{-1}$, with the differential pressure across the canister measured using the magnehelic transducer. This measurement was essential to ensure that the canister, when saturated with isoflurane, does not add a resis- 


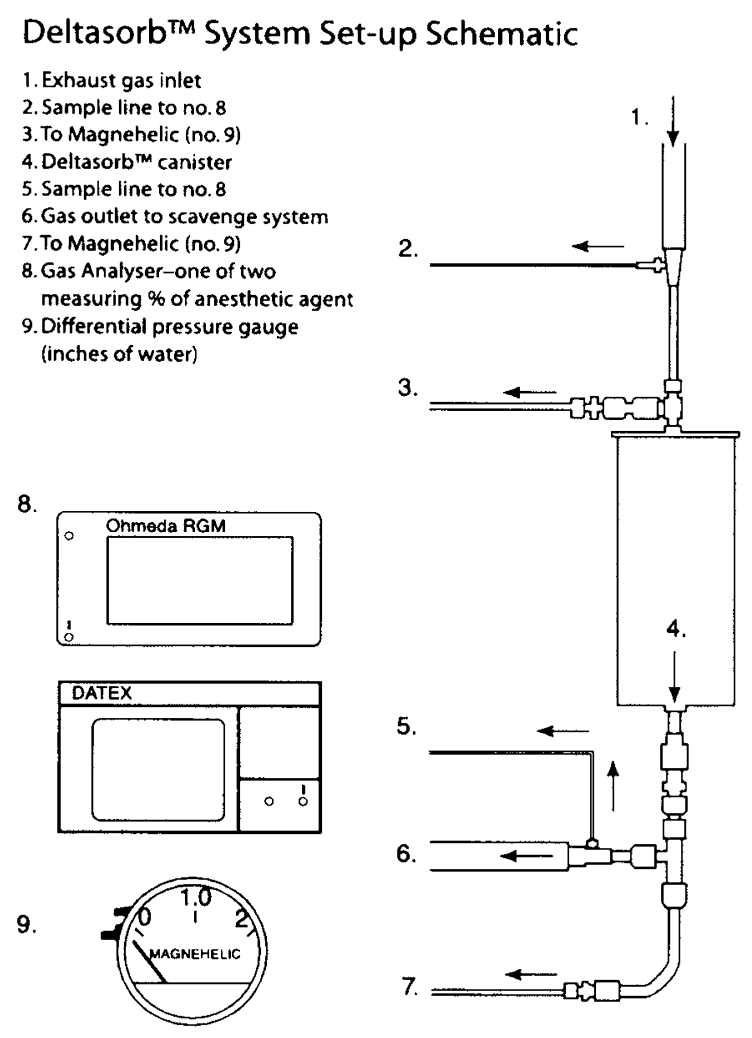

FIGURE 4 Deltasorb ${ }^{\text {TM }}$ system set-up schematic. 1) exhaust gas inlet; 2) sample line to no $8 ; 3$ ) to magnehelic (no 9); 4)

Deltasorb $^{\mathrm{TM}}$ canister; 5 ) sample line to no 8); 6) gas outlet to scavenge system; 7) to magnehelic (no 9); 8) gas analyzer - one of two measuring \% of anesthetic agent; 9) differential pressure gauge (inches of water).

tance to the scavenging system that exceeded Canadian Standards Association (CSA) recommendations. ${ }^{8}$ These recommendations state that "a scavenging system shall not increase the resistance to expiration over and above that imposed by the breathing system by more than $0.5 \mathrm{~cm} \mathrm{H}_{2} \mathrm{O}$ at continuous

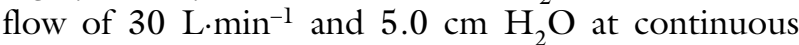
flow at $90 \mathrm{~L} \cdot \mathrm{min}^{-1} " .8$

At the beginning of phase 1 , the isoflurane vaporizer was weighed both empty and full of isoflurane. The prototype canister was also weighed before and after phase 1 of each experiment. All other measurements were made at $15-\mathrm{min}$ intervals throughout phase 1. These measurements included: mean inspired isoflurane concentration, end-tidal isoflurane concentration, end-tidal $\mathrm{CO}_{2}$, airway pressures, flow into the anesthetic circuit, the isoflurane concentration entering the canister, the isoflurane concentration exiting
TABLE Summary of data from three experiments $(A, B, C)$ in which humidified 'exhaled' gas, containing $\mathrm{CO}_{2}$ and isoflurane from the simulated anesthesia mannequin was passed through a canister of silica zeolite attached to the scavenging system of the anesthesia machine

\begin{tabular}{|c|c|c|c|}
\hline & $A$ & $B$ & $C$ \\
\hline $\begin{array}{l}\text { Weight of vaporizer at } \\
\text { the beginning of phase } 1\end{array}$ & $5104 \mathrm{~g}$ & $5073 \mathrm{~g}$ & $5075 \mathrm{~g}$ \\
\hline $\begin{array}{l}\text { Weight of vaporizer at } \\
\text { the end of phase } 1\left(6^{1 / 2} \mathrm{hr}\right)\end{array}$ & $5016 \mathrm{~g}$ & $4973 \mathrm{~g}$ & $4987 \mathrm{~g}$ \\
\hline Isoflurane used & $88 \mathrm{~g}$ & $100 \mathrm{~g}$ & $88 \mathrm{~g}$ \\
\hline $\begin{array}{l}\text { Weight of canister at } \\
\text { beginning of phase } 1\end{array}$ & $3434 \mathrm{~g}$ & $2939 \mathrm{~g}$ & $2950 \mathrm{~g}$ \\
\hline $\begin{array}{l}\text { Weight of canister at } \\
\text { end of phase }\left(6^{1 / 2} \mathrm{hr}\right)\end{array}$ & $3491 \mathrm{~g}$ & $3015 \mathrm{~g}$ & $3022 \mathrm{~g}$ \\
\hline $\begin{array}{l}\text { Weight increase of } \\
\text { canister }(\mathrm{g})\end{array}$ & $57 \mathrm{~g}$ & $76 \mathrm{~g}$ & $72 \mathrm{~g}$ \\
\hline
\end{tabular}

the canister, flow exiting the canister, the differential pressure across the canister, temperature of the expired gas, and the concentration of nitrous oxide and oxygen exiting the canister.

\section{Results}

\section{Phase 1}

The purpose of phase 1 was to assess the effectiveness of silica zeolite in removing isoflurane from exhaled, humidified gas (containing $\mathrm{CO}_{2}$ ) for the equivalent of one day's use in the operating room (approximately $6.5 \mathrm{hr}$ ) under similar conditions. The 6.5-hr pilot study was completed on three occasions (experiments $\mathrm{A}, \mathrm{B}$ and $\mathrm{C}$ ). The weight of both the isoflurane vaporizer and the canister at the beginning and at the end of phase 1 are shown in the Table for each experiment. The average weight of isoflurane used in the three experiments was $92 \mathrm{~g}$ and the average weight increase in the canister (phase 1) was $68 \mathrm{~g}(n=3)$.

In all three experiments, the inspired isoflurane concentration was maintained at 1.0-1.1\% throughout the study. The end-tidal concentration of isoflurane, measured at 15 -min intervals, ranged from $0.8 \%$ to $1.1 \%$. The end-tidal concentration of $\mathrm{CO}_{2}$ was maintained between 35-41 mmHg. The temperature of humidified, exhaled gas entering the carbon dioxide absorber ranged from $26-29^{\circ} \mathrm{C}$. Changes in airway pressure were not detected throughout the study period (average 19/2 $\mathrm{cm} \mathrm{H}_{2} \mathrm{O}$ ).

The concentration of isoflurane entering the canister increased to equal the end-tidal concentration within $15 \mathrm{~min}$, and ranged from $0.8 \%$ to $1.0 \%$ throughout the study. The concentration of isoflurane 
exiting the canister remained undetectable $(0 \%)$ throughout the $6.5 \mathrm{hr}$ of phase 1 in all three experiments. The concentration of $\mathrm{N}_{2} \mathrm{O} / \mathrm{O}_{2}$ in the gas exiting the canister was measured and ranged from $47 \%$ to $52 \%$ throughout the study. The differential pressure measured across the canister was $0.13 \mathrm{~cm} \mathrm{H}_{2} \mathrm{O}(.05$ inches $\mathrm{H}_{2} \mathrm{O}$ ) and did not increase during phase 1 .

\section{Phase 2}

The purpose of phase 2 was to establish if and when 'breakthrough' would occur with approximately $750 \mathrm{~g}$ of silica zeolite in a canister. Since no 'breakthrough' of isoflurane was detected during phase 1 , the simulated anesthesia mannequin was replaced with a test lung (2.0- $\mathrm{L}$ anesthetic bag). The gas exiting from the canister was continuously monitored to detect the time required for 'breakthrough'. The total time (phase $1+$ phase 2 ) required for detection of 'breakthrough' was eight hours, $8.8 \mathrm{hr}$ and nine hours in the three experiments. At this time, the differential pressure across the canister had not increased and no change in airway pressure was detected.

After 'breakthrough' had occurred in experiment three, the experiment was continued for $18 \mathrm{hr}$ until the silica zeolite was saturated with isoflurane. Saturation was achieved when the concentration of isoflurane in gas exiting the canister was equivalent to that entering the canister ( $1 \%)$. The pressure differential across the canister was measured at high flow rates (30 L. $\mathrm{min}^{-1}$ and $90 \mathrm{~L} \cdot \mathrm{min}^{-1}$ ). The pressure measured was $0.64 \mathrm{~cm} \mathrm{H} \mathrm{H}_{2} 0$ with $30 \mathrm{~L} \cdot \mathrm{min}^{-1}$ continuous airflow, and $2.34 \mathrm{~cm} \mathrm{H}_{2} 0$ with $90 \mathrm{~L} \cdot \mathrm{min}^{-1}$ flow.

\section{Discussion}

This study verifies that silica zeolite was effective at completely removing $1 \%$ isoflurane from exhaled, humidified gas containing $\mathrm{CO}_{2}$ under simulated operating room conditions for $6.5 \mathrm{hr}$. These data support Janchen's conclusions from a clinical study, in which $62-86 \%$ of delivered desflurane was adsorbed by a silica zeolite. ${ }^{7}$ In our study, approximately $750 \mathrm{~g}$ of silica zeolite resulted in complete removal of $1 \%$ isoflurane at a fresh gas flow rate of $3 \mathrm{~L} \cdot \mathrm{min}^{-1}$ for eight to ten hours before breakthrough $(0.02 \%)$ occurred. In Janchen's clinical study, fresh gas flow affected the efficiency of adsorption of exhaled desflurane. ${ }^{7}$ With low-flow conditions $\left(0.5 \mathrm{~L} \cdot \mathrm{min}^{-1}\right) 62 \%$ of the desflurane was adsorbed, whereas under high-flow conditions $\left(3 \mathrm{~L} \cdot \mathrm{min}^{1}\right)$ they reported $86 \%$ adsorption. In phase 1 , we studied only a relatively high fresh gas flow rate $\left(3 \mathrm{~L} \cdot \mathrm{min}^{-1}\right)$ to assess the effect of this canister on the function of the anesthesia machine and the scavenging system. At this relatively high fresh gas flow rate, no increase in pressure or ventilator malfunction was detected.

Several assumptions were made in designing this simulated clinical study. In phase 1 , we assume that the increased weight of the canister (Table) was caused by adsorbed isoflurane. If this is true, only $74 \%(68 \mathrm{~g})$ of the used isoflurane $(92 \mathrm{~g})$ is adsorbed in the canister (Table). This compares with $86 \%$ of desflurane under clinical circumstances in Janchen's study. ${ }^{7}$ Under low- flow anesthesia, lower efficiency can be expected. Clearly, leaks from the anesthesia circuit and from the simulated anesthetic mannequin may have influenced the efficiency of recovery in our study. In clinical practice, uptake and distribution of anesthetics by the patient will be important determinants of the efficiency of recovery.

Janchen's study ${ }^{7}$ reported that about $85 \%$ of the adsorbed desflurane could be recovered, by desorption, as high quality liquid anesthetic with high purity. Commercial feasibility of this process is uncertain, however recovery rate will clearly be an important determinant of the reclamation process efficiency. The molecular sieve structure (Figure 1) of silica zeolite, allows small molecules to pass through. We suspect that little of the added weight was due to water accumulation in the canister, since the zeolite used is hydrophobic. Such non-polar surfaces have no electrostatic interaction with the small, polar water molecules which are held only weakly and are easily displaced by organics. ${ }^{6}$ The fact that the concentration of nitrous oxide exiting the canister was $47-52 \%$ when the inhaled concentration was $50 \%$ suggests that the small molecules $\left(\mathrm{N}_{2} \mathrm{O}\right)$ did traverse the silica zeolite in the canister.

In phase 2 , the pressure gradient across the canister was negligible at a gas flow rate of $3 \mathrm{~L} \cdot \mathrm{min}^{-1}$, even as 'breakthrough' was approached. However, the pressure gradient across the canister, which was saturated with isoflurane, at a fresh gas flow rate of $30 \mathrm{~L} \cdot \mathrm{min}^{-1}$ was $0.64 \mathrm{~cm} \mathrm{H}_{2} \mathrm{O}$. This exceeds the current CSA standard maximum of $0.5 \mathrm{~cm} \mathrm{H}_{2} \mathrm{O}$, while the pressure gradient with $90 \mathrm{~L} \cdot \mathrm{min}^{-1}$ air flow rate $\left(2.64 \mathrm{~cm} \mathrm{H}_{2} \mathrm{O}\right)$ was within CSA standards (maximum $5 \mathrm{~cm} \mathrm{H}_{2} \mathrm{O}$ ). ${ }^{8}$ These are standard test conditions used for anesthesia circuits. Since 'breakthrough' occurred after approximately eight hours, we anticipate that the efficiency of $750 \mathrm{~g}$ of silica zeolite will decrease after one day of continuous use in the operating room. To optimize efficiency of anesthesia vapour recovery and minimize chances of increased pressure in the anesthetic breathing system, minor changes in canister design to reduce resistance when zeolite is saturated are required.

We conclude that scavenging of waste halogenated hydrocarbons from anesthesia circuits is effective 
using this silica zeolite adsorbent. When interposed in the scavenging system of an anesthetic circuit, this prototype canister did not increase airway resistance when isoflurane 'breakthrough' occurred. This scavenging method is feasible in a clinical environment. Some modifications need to be made to the prototype canister to reduce the differential pressure across the device at high flow rates; however the pressure reductions required are small and should be achieved before clinical testing is undertaken.

\section{References}

1 Dorsch JA, Dorsch SE. Understanding Anesthesia Equipment: Construction, Care and Complications, 4th ed. Baltimore: Lippincott, Williams \& Wilkins, 1999.

2 Baum JA, Aitkenhead AR. Low-flow anaesthesia. Anaesthesia 1995; 50: 37-44.

3 Logan M, Farmer JG. Anaesthesia and the ozone layer (Editorial). Br J Anaesth 1989; 63: 645-7.

4 Langbein T, Sonntag H, Trapp D, et al. Volatile anaesthetics and the atmosphere: atmospheric lifetimes and atmospheric effects of halothane, enflurane, isoflurane, desflurane and sevoflurane. Br J Anaesth 1999; 82: 66-73

5 Flanigen EM, Bennett JM, Grose RW, et al. Silicalite, a new hydrophobic crystalline silica molecular sieve. Nature 1978; 271: 512-6.

6 Kirk RE, Othmer DF. Adsorption. In: Kroschwitz J, Howe-Grant M (Eds.). Kirk-Othmer Encyclopedia of Chemical Technology, $4^{\text {th }}$ ed., vol 1. New York: John Wiley \& Sons, Inc., 1991: 493-527.

7 Janchen J, Bruckner JB, Stach H. Adsorption of desflurane from the scavenging system during high-flow and minimal-flow anaesthesia by zeolites. Eur J

Anaesthesiol 1998; 15: 324-9.

8 Canadian Standards Association. Anaesthetic Gas Scavenging Systems. A National Standard of Canada. CSA International CAN3-Z168.8 - M82. (Reaffirmed 1994). 